Psychotherapy as a Human Science: Clinical Case Studies Exploring the Abyss of Madness

Pragmatic Case Studies in Psychotherapy, http://pscp/libraries.rutgers.edu

Volume 8, Module 1, Article 1, pp. 1 - 24, 02-18-12 [copyright by author]

EDITOR'S NOTE FOR VOLUME 8, MODULE 1: This issue's target article, by George Atwood, is an expansion and revision of the first chapter of his recently published book, The Abyss of Madness (2011, Routledge). Those interested in further pursuing Atwood's innovative and important perspective on psychotherapy with individuals experiencing severe emotional disturbance are encouraged to read the book.

A major theme in Atwood's article is that unlike the usual view of schizophrenic and bipolar symptoms as evidence of a brain disease, i.e., as "outward signs of an inward illness," Atwood views such symptoms as "reactions to such ongoing experiences as devastating abandonment, felt misunderstanding, and re-traumatization" (p. 1-2). In line with this, Atwood argues and illustrates that therapeutic help for individuals with schizophrenic and bipolar symptoms involves entering and understanding their subjective worlds and helping them to navigate within those worlds to work towards more functional lives. This theme is strongly supported by two topical, case-based projects that recently crossed my desk. The first is a study of individuals "who are functioning normally despite severe mental illness and have chosen to speak out about their struggles." Five of these individuals are described in a 2011 New York Times series of articles by the science and medical journalist Benedict Carey, under the title, "Lives Restored" (http://www.nytimes.com/interactive/science/lives-restored-series.html). The second project is a doctoral dissertation by Paris Williams (2011), a psychologist who herself has struggled with psychosis, that qualitatively and systematically explores the "personal paradigm shifts" of six formerly psychotic individuals "throughout the psychotic process, from onset to full recovery" ( $p$. ii). The approach in both projects-creating case studies of the experiences, inner worlds, and strategies in part created by the individuals themselves to seek a positive path out of severe dysfunction and despair-seems to me most promising for supporting and expanding Atwood's approach to helping such individuals by identifying the therapeutic conditions that facilitate the development of these positive paths.

\title{
Psychotherapy as a Human Science: Clinical Case Studies Exploring the Abyss of Madness
}

\section{GEORGE E. ATWOOD ${ }^{\mathrm{a}, \mathrm{b}, \mathrm{c}}$}

\author{
a Department of Psychology, Rutgers University. \\ ${ }^{\mathrm{b}}$ Correspondence concerning this article should be addressed to George E. Atwood, Tillett Hall 509, \\ Livingston Campus, 53 Avenue E, Piscataway, NJ, 08854 \\ C I wish to express my profound gratitude to Dan Fishman, who assisted substantially in the process of expanding \\ and completing this article. \\ Email: ufoatw01@earthlink.net
}

\begin{abstract}
This paper presents examples of my clinical work that illustrate a phenomenologically, humanistically, existentially, and psychodynamically informed approach to severe psychological disturbances, including both so-called schizophrenia and so-called bipolar disorder. I illustrate how "symptoms" that appear in this realm can be seen not as outward signs of an inward illness,
\end{abstract}


Psychotherapy as a Human Science: Clinical Case Studies Exploring the Abyss of Madness

but as reactions to such ongoing experiences as devastating abandonment, felt misunderstanding, and re-traumatization. Following this, I imagine a world of psychiatry and psychology as a human science, one that has escaped the hegemony of the medical model and grounds itself in the study of human lives as they are lived and experienced. In this world, the therapist has a radical engagement with the client, with the therapist's subjectivity being everywhere present in the psychotherapeutic process. Here, there is no such thing as detached observation; and if a psychotherapeutic dialogue is in any measure successful, it always illuminates and transforms the worlds of both of the people involved.

Key words: phenomenology; psychosis; schizophrenia; bipolar disorder; humanistic psychology; therapeutic relationship; psychodynamic theory; case studies; clinical case studies

When I was a student first entering college, in a burst of youthful enthusiasm, I had the thought that the psychotherapy of severe mental illness offered an opportunity to discover the secrets of the human mind and the depths of human nature. I have had the good fortune to actually devote my life to this quest, and this essay brings together some of the things that have emerged in the course of nearly 50 years working in the field.

I cannot claim that my journey has unraveled the mystery of the psyche, but I can say it has brought me to ideas and understandings that, to me anyway, seem significant and interesting. The material develops in the form of a series of reflections covering important clinical experiences and associated theoretical and philosophical reflections on the nature of the psychotherapy process.

\section{THE CASE OF GRACE}

Every psychotherapist has one early case that shapes his or her destiny as a clinician. The following account tells the story of a woman from whom I learned about psychosis, and about what is required of a therapeutic experience in order that the patient's devastation be addressed and healed. The work occurred as part of a postdoctoral fellowship in clinical psychology at Western Missouri Mental Health Center in Kansas City Missouri, from 1969 to 1972. What made this institution of interest to me was that its director of clinical training was Austin Des Lauriers, a renowned psychotherapist and author of The Experience of Reality in Childhood Schizophrenia (1962). Des Lauriers was my clinical consultant in the unfolding of the experiences described.

First, a word about my initial encounter with the patient, a 28 year-old woman whom I shall call Grace: Early one morning - it was 3am - she came into the screening clinic at the hospital where I was being trained, shouting and carrying on. Her hair was disheveled, her eyes were wide with excitement, and perspiration drenched her clothes. She demanded to see someone important. I presented myself as that person and sat down to hear her story. A few hours earlier, Grace had experienced an invasion of her bedroom by dazzling flashes of golden light, and she said the flashes had also somehow penetrated into her body I asked her what she thought this event was. She answered, in loud tones: 
Psychotherapy as a Human Science: Clinical Case Studies Exploring the Abyss of Madness

Pragmatic Case Studies in Psychotherapy, http://pscp/libraries.rutgers.edu

Volume 8, Module 1, Article 1, pp. 1 - 24, 02-18-12 [copyright by author]

I had sexual intercourse with Jesus Christ! . . .

I am filled with His energy and I am about to BUST!

For many years, the patient had carried the diagnosis: Schizophrenia, paranoid type - DSM II: 295.3. She fulfilled all the criteria: clear signs of thought disorder, inappropriate affect, hallucinations, delusions of grandeur.

Under Des Lauriers’ (1962) guidance, I arranged to have daily meetings with the patient. I saw her 5 days a week. She was placed on phenothiazine therapy, and while the drugs certainly slowed her down, they seemed to have no effect on the religious delusions she expressed. Her delusional life was quite involved, and in the early months of my work with her I made an effort to become acquainted with its full extent. I also collected a detailed history, from her and from various family members.

She was deeply involved with God, the Catholic Church, and a special destiny she envisioned for her life on our planet. She considered herself to be the earthly incarnation of the Holy Spirit, a member of the Trinity, and saw her role as one of exercising a peace-making force upon the world as a prelude to the Second Coming of Christ and the End of the World.

From a logical point of view, this patient's delusions were inconsistent with one another in a number of respects, but if one looked at them symbolically one could discern the presence of repeating themes. She envisioned herself as a member of the Holy Trinity, incarnated to help bring about the coming of our Lord and Savior, setting the stage for her ascension into Everlasting Life in Heaven and the Resurrection and Salvation of all humanity. She believed that God the Father and God the Son had also taken on earthly form and were present in two individuals of her personal acquaintance. God the Father, she said, resided inside the Bishop of her diocese, a man for whom she had worked as a church volunteer in earlier years of her life. God the Son, Jesus Christ Himself, was present in another man who had served as her counselor during her late teen years. This person, also a devoted Catholic, had tried to help my patient with some very dark depressions that came upon her as a young woman. She had developed great love for this counselor, but their relationship ended when she was 19 and suddenly became psychotic. Although she had not seen him for almost a decade, she looked forward to a joyful reunion within the Trinity at the End of the World.

My patient seemed to entertain fantasies that she might be pregnant, often crying out in the mornings:

\section{I feel nauseated, and I am in pain!}

One day, I impulsively responded to this statement by telling her not to worry, because she was not pregnant. She reacted with gales of laughter. Although she never made overt claims to being the Mother of Christ, it was apparent that she was identifying with the Holy Virgin. She also believed she had a personal relationship with the Holy Father in Rome, often experiencing vivid hallucinatory flights through the sky to the Vatican, where she would descend from above and be gently deposited upon the lap of the Pope. The College of Cardinals, according to her further explanations, was giving consideration to canonizing her, and she eagerly awaited a proclamation from Rome that her sainthood had been declared. 
Psychotherapy as a Human Science: Clinical Case Studies Exploring the Abyss of Madness

Pragmatic Case Studies in Psychotherapy, http://pscp/libraries.rutgers. edu

Volume 8, Module 1, Article 1, pp. 1 - 24, 02-18-12 [copyright by author]

Let me now turn to what I came to understand as a pivotal tragedy that occurred during her childhood. She suffered the experience of what is probably the single most injurious thing that a parent can do to a child: the suicide of her deeply beloved father. It took place when she was 10 years old, shattered her mother and really her whole family - there were also two brothers - and she had no one to help her deal with its cruel aftermath. One afternoon, without any warning, her father had slashed his wrists and hanged himself from a tree.

An event such as this is indescribably destructive. In addition to constituting a traumatic loss, suicide retroactively invalidates the relationship the child had believed in prior to the death. Because it is a willful act, something the parent has chosen to do, a statement has been made as to the significance of the child to that parent. So the very reality of the child's world is attacked by a parent's suicide. All that was believed to be true has been suddenly rendered meaningless, faith in one's own perceptions and thinking is therefore assaulted, and the child is left with the knowledge, never before considered even as a possibility, that he or she was not worth living for. A child having undergone such an experience is in need of very significant support in finding a way to survive what has happened that will not progressively destroy his or her life. But generally the other family members are so traumatized by the death that they are completely unavailable to each other, and this greatly compounds and complicates the situation. All of these things came into play in my patient's early years.

How did Grace go from the tragedy of her father's death to membership in the Holy Trinity? How does someone move from a devastating suicide to a messianic destiny to bring on the End of the World? As I listened to my patient's sad story, I wondered about these things. One could never ask her such questions though, because in her delusions she was not able to have any kind of ordinary conversation. Whenever the topic of these ideas came up in our meetings, she quickly became carried away with excitement and filled up with feelings of godlike power. If I was unwise enough to ask, for example, why she thought her counselor was the reincarnation of Jesus Christ—and in the early going I often asked very ill-considered questions — she would bound out of her chair and cry out:

I am the Truth, I am the Way, I am the Light, or

The suffering, the sorrow, the PAIN, or

It is the HUMAN side of Jesus Christ, not the DIVINE!

I learned to avoid such direct inquiries into the details of her religious life, and for short periods in our initial meetings I found it possible to engage her in fairly coherent discussions of her childhood background and of very concrete aspects of her program in the hospital.

The answer to the question as to how she went from the father's death to her delusions and hallucinations concerns the pathway she tried to find in the years following the tragedy. It was a pathway of inwardness, of secret prayer, of an attempted drawing close to God, of seeking comfort in the arms of Jesus. She made a kind of pact with her Savior: if He would accept her into a state of rescuing union with Him, she would transform herself and become a purely spiritual being. Telling no one living of her secret commitments, Grace tried to enact the planned union with God by entering a convent at age 17, with the idea of becoming a nun and a missionary and devoting the remainder of her earthly existence to works of self-sacrifice on behalf of the poor and the sick. She tried mightily, as an aspect of this striving toward oneness 
Psychotherapy as a Human Science: Clinical Case Studies Exploring the Abyss of Madness

Pragmatic Case Studies in Psychotherapy, http://pscp/libraries.rutgers.edu

Volume 8, Module 1, Article 1, pp. 1 - 24, 02-18-12 [copyright by author]

with her God, to purge herself of every trace of self-interest and personal need, including the whole of her emerging sexuality. She was unable to complete the course of study at the convent, however, and after a year of struggle collapsed into a black depression. This was the time at which she began to receive counseling from a man who was a member of her church and who worked with many priests and nuns.

I am not going to go into the details of their sessions together, although she did describe them fully to me. Suffice it to say that she latched on to her counselor as her Savior, and without telling him what she was thinking began to entertain the notion that at last she had found Jesusthat a miracle had appeared in her life and her counselor was himself the Lord her God. But the spiritual attraction and joy she felt on having at last arrived in His presence was disturbed by other feelings: a confusing, dismaying sexual intensity began to color her tie to her counselor, and she was unable to suppress longings for physical, erotic contact with him. She also began to feel that he was not listening to her, and in spite of his exalted status as a quasi-deity that he did not care about her suffering. Never saying anything directly regarding these matters, one day, without warning or explanation, she arose in his office and shouted out these words:

\section{JESUS CHRIST ABANDONED ME!}

Following this announcement, Grace walked out and their meetings were discontinued. A few days later she was hospitalized for the first time, already deeply immersed in the delusional fantasies that were present when I first became acquainted with her. Her counselor made no effort to contact her and she made none to find him. There was nevertheless the fluctuating idea present in her mind that in him she had found God.

Over the course of the next 6 years, Grace went back and forth between relative stability and states of deep religious preoccupation. There were at least 10 separate hospitalizations during this period, some of them lasting months in duration. Finally, shortly after her $28^{\text {th }}$ birthday, in the midst of the latest resurgence of her hallucinations and delusions, she and I found each other.

I spent a lot of time with her, visiting her almost every day for the first 6 or 7 months, sometimes for as long as two hours. I could see in the course of these meetings that she was becoming very attached to me-I always found her eagerly waiting when I arrived at the hospital each morning, and she was the last to say goodbye when I left in the evening. There was, however, no particular improvement that was visible as the streaming of her religious fantasies continued, sometimes becoming so intense as to preclude any meaningful conversation. Often she behaved in an imperious manner, barking out orders about what she wanted me to do for her, and promising that if I would comply she would repay my efforts by raising my consciousness and helping me become a spiritually powerful person in my own right. She once stared deeply into my eyes and cried out:

Doctor! I am going too raise you up, from here [gesturing toward her knees] to HERE [raising her hands high over her head and shouting]!

She became intolerant of any response I made to her words that did not seem to her connected with whatever she was trying to convey, many times angrily screaming out: 
Psychotherapy as a Human Science: Clinical Case Studies Exploring the Abyss of Madness

Pragmatic Case Studies in Psychotherapy, http://pscp/libraries.rutgers.edu

Volume 8, Module 1, Article 1, pp. 1 - 24, 02-18-12 [copyright by author]

\section{Stop cutting me off, you're cutting me off, STOP CUTTING ME OFF!}

Such moments were extremely difficult, to say the least, especially because the ideas she was expressing were almost always matters of barely comprehensible, often incoherent religious revelations. In addition to her words, she presented a series of paintings she had completed some time before. These were chiefly concerned with religious themes, such as the Crucifixion, the Resurrection, and the Holy Virgin, but others displayed images of fire and destruction, with the words "I AM PAIN," "I AM ANGER," or simply "I AM," scrawled across the canvases in large capital letters.

One day, many months into our relationship, she informed me that there was a secret project she had been working on for more than two years that was now on the threshold of completion. I asked her what this project entailed, and she answered, again shouting:

\section{MY PLAN TO REACH MY GOLD!}

At first I did not understand her words, and I asked: "Your goal?” She then roared:

MY GOALLLLLLL ........... .D!

Seeming to condense the words “goal” and “God,” this plan involved, as I learned with great difficulty, a program of clandestine meditations and prayer she had developed that were producing healing, loving effects sweeping across the world. She was channeling, via the meditations, God's Love, which then was being transmitted to all humanity. The purpose of this was to bring about world peace, and also to create the conditions for the Second Coming of Christ and the End of the World. In order for the Plan to be executed, she imagined it would be necessary for her to have a reunion with her old counselor, the man she had identified as Christ on Earth. Following their coming together, the two of them would then join with the Bishop and ascend into Heaven in a burst of radiant glory as the Trinity. The End of the World could then unfold, the souls of all mankind would stand in Judgment, and the Final Ascension of all into Heaven could then take place. "Reaching my gold" meant achieving union with God, the deity that had come to her many months before in the form of miraculous golden light. The patient then gave her instructions:

I want you to call Dr. S., my old counselor, and arrange for me to meet with him. YOU WILL DO THIS!

When I at first hesitated in the face of this demand, expressing doubt as to its wisdom, she furiously responded:

LISTEN UP, YOU! If you want to know me and be associated with me, you will be a part of my Plan and do as I say! NOW!

This was the crisis point in our evolving relationship: I had been given a choice between participating in her journey and following her orders, or refusing and therefore dropping out of her life. I found her to be almost irresistibly forceful in presenting this demand and was very unsure as to how to respond. I managed to put her off by promising to give her my answer the next day. 
Psychotherapy as a Human Science: Clinical Case Studies Exploring the Abyss of Madness

Pragmatic Case Studies in Psychotherapy, http://pscp/libraries.rutgers.edu

Volume 8, Module 1, Article 1, pp. 1 - 24, 02-18-12 [copyright by author]

By this time, we had spent more than 120 hours together, increasingly, it seemed to me, immersed in her passionate religious expressions. One day when I was playing a game of pool with another patient, she burst into the game room, pushed us out of the way, and held the white cue ball high in the air. She cried out:

\section{THIS IS THE HOLY GHOST!}

She then shot the cue ball with great power, and showed intense satisfaction as a number of the balls flew off the pool table.

On another occasion, following a very difficult two-hour conversation with me on various religious topics, she ran into a room where other patients were playing a game of bingo. Standing before them, she announced in loud tones:

\section{LORD I AM CURED! LORD I AM SAVED! LORD I AM JOY! DO YOU KNOW WHO HAS SAVED ME? THAT WONDERFUL MAN, DR. A. WHOOPPEEEEEEEEE!}

Some very serious thinking occurred the night following her instructions regarding the planned reunion with her old counselor. This included a short consultation with my supervisor, Dr. Austin Des Lauriers, who believed psychotherapy was the most important of all things in the treatment of schizophrenia. He suggested standing up to her demands with a countering firmness, one that would more fully establish my presence in her world as the ground of her eventual healing and recovery. He thought that all her extravagant orders and threats were bids for a strength outside herself that she could finally rely on, and that it was up to me to help her find that strength in the connection she and I had been building now for many months. Des Lauriers told me it was time for me to rise and shine.

The next day, I saw her in the late afternoon, and this time our meeting was a very different experience, for both of us. When we sat down and she was about to launch into her Plan and its associated instructions, I stopped her by asking her to be quiet and listen to some things I had to say. When she shouted I was "cutting her off," I answered that I was not; furthermore, now she was the one doing the cutting off, and she needed to stop and listen to me instead. Finally she was silent. I spoke the following words, trying to use a calm but very firm voice.

We have been spending time with each other for days and weeks and months, and I have listened to everything you have told me very carefully. Now I have something to say to you, and you must hear this clearly. There has been a lot of talk about a plan. I want you to know that I have a new plan now, a plan for you, and in my plan you are going to get well, and you will be able to return from the hospital and be with the people who love you. In terms of any meetings to be arranged, there are to be no meetings with anyone except for the ones between you and me, because it is in our work together that the plan I am telling you about will be fulfilled. There is only one person on this earth you need to be concerned about seeing. I am that person.

She tried at first to interrupt me as I gave this little speech, but each time she did so I stopped her and insisted again that she hear what I had to say. Then I repeated the presentation in somewhat different words. This had to occur perhaps three times. Finally she objected no more and, after a 
Psychotherapy as a Human Science: Clinical Case Studies Exploring the Abyss of Madness

Pragmatic Case Studies in Psychotherapy, http://pscp/libraries.rutgers.edu

Volume 8, Module 1, Article 1, pp. 1 - 24, 02-18-12 [copyright by author]

short period of silence, began to cry. I had never seen her cry before this moment. She cried and cried, and then she cried some more. Half an hour passed, and, finally, she said:

\section{Thank you. I am leaving now.}

The next day I came into the hospital, curious, and worried, about what had transpired as a result of our encounter. My patient was not there; somehow she had persuaded the hospital staff to give her a pass to spend the day at home with her mother. I called her home to see what was occurring, and the mother, whom I had met and spoken to many times, said to me:

Doctor, what did you do? My daughter is herself again! She came home this morning and sat with me, drinking tea on the porch, and catching up on the latest news and gossip about our neighbors. What has happened? She is herself! She is the girl I used to know who disappeared a long time ago! This is a miracle!

I saw the patient soon after these developments, and was astonished to find someone completely sane, very interested in the everyday world and without a trace of the religious preoccupations that had dominated her life and thinking now for many years. She spoke of interests in leaving the hospital, getting a job, and helping her mother in taking care of the house where she lived. It was shocking to witness this change. Overnight., as an apparent effect of 30 minutes of conversation, a raging paranoid schizophrenia, a volcano of florid symptomatology, had disappeared and been replaced by a perfectly normal person. I have never been able to see the phenomena of psychosis in the same way again. It also led me to conclude that those who say so-called schizophrenia cannot be helped by psychotherapy don't know what they are talking about. One needs to have experiences like this in order to learn what is and is not possible.

Grace did fall back a number of times, sometimes violently, again becoming swept away in the religious imagery and the expectations of union with God in Heaven. In each instance though, I reiterated my little spiel, with continuing good effects on her. She was able to leave the hospital a few weeks later, and in the ensuing years did well. She needed my support for a long period, and, during the first year following our breakthrough, often responded to me as if I possessed some sort of miraculous power and enormous significance. I did not comment on such attributions, because I thought they reflected her dependence on our connection as her shattered personal universe was in the process of being reassembled. But she really asked for very little. It was kind of odd that once I established the omnipotent plan I had for her, I didn't have to do much of anything other than remain emotionally available. I watched her in the years afterwards come into her own as her initial extreme dependence on our frequent contacts gradually diminished. I also saw her contend with the awful legacy of her father's decision to end his life. She spoke to me and to her family members at great length regarding her sadness and furious anger with him for choosing to kill himself. She did well for the next thirty years, but died suddenly as a result of a cardiac infarction at age 58 .

The ending of the story is especially sad because Grace was one of the best people I have ever known. I had contact with her, sometimes sporadic, throughout the remaining years of her life, and I can say she was a joy to her family and friends. She loved animals and was instrumental in rescuing a great many dogs and cats. She remained a deeply religious Catholic, 
Psychotherapy as a Human Science: Clinical Case Studies Exploring the Abyss of Madness

Pragmatic Case Studies in Psychotherapy, http://pscp/libraries.rutgers.edu

Volume 8, Module 1, Article 1, pp. 1 - 24, 02-18-12 [copyright by author]

attending Mass almost every day. This world would be a better place if there were more such people.

\section{Reflections on Grace's Case}

In its simplest terms, the impact of this clinical experience concerned my learning to view the phenomena of "psychosis" as relative to a certain situational context, rather than as arising solely from a pathological process occurring somehow inside the patient. My understanding was that my patient had been seeking a response from her world to help her deal with the devastation flowing primarily from her father's suicide. Although I did not tell this part of the story earlier, when she was young she had tried to find help from her mother, her brothers, her teachers, and her priest. Her family members had closed down as a consequence of their own very profound trauma, and no one outside her family understood her cries for help. The abandonment space into which her life had fallen created the setting within which she turned to the Son of God. Having been deserted by her father, her family, and, from her point of view, everyone else, she looked for what she needed outside and beyond the world, to her Father in Heaven. Again, however, her unfolding journey through her teen years was punctuated by repeating abandonment shocks, as all her efforts to bring God into the heart of her being did not succeed and instead were rewarded only by a deepening loneliness and despair. These were the conditions within which a spiraling into a delusional reconstruction of a shattered personal world occurred.

Then comes the part of the story in which I was involved. When I finally recognized the importance of standing up to her imperious grandiosity, and found a way to do so that would help her see she was in the presence of someone she could depend on, the destructive course of events in her life began to turn around. Having discovered what she needed in our developing connection, the delusions and hallucinations receded. Very gradually, in the crucible of her extreme dependence, the healing process that had been aborted years earlier in her life now had a chance to occur.

Grace’s "symptoms," therefore, were not just outward signs of an inward illness; they were reactions to an ongoing experience of continuous abandonment and devastation at the hands of an uncomprehending world. They were desperate cries for help. It occurred to me that perhaps all the symptoms we see in the most severe ranges of so-called "mental illness" are analogously embedded in contexts of felt unresponsiveness, misunderstanding, and never-ending retraumatization. Such an idea leads to a far more optimistic view of these conditions as to the possibility of some sort of recovery. Maybe, I thought, an understanding of this could inspire us to rethink the problem of psychotherapy for our most extreme cases.

\section{"SO CALLED" SCHIZOPHRENIA: THE CASE OF ANNA}

Whenever I use the word "schizophrenia," I have found myself prefacing it with the words "so-called." The experience with Grace and many analogous ones with other patients subsequently have led me to this way of speaking.. "Schizophrenia," meaning "split-mind,," was coined one hundred years ago by the Swiss psychiatrist, Eugen Bleuler (1911), who hoped to reinterpret the field of psychopathological phenomena previously grouped under the label, 
Psychotherapy as a Human Science: Clinical Case Studies Exploring the Abyss of Madness

Pragmatic Case Studies in Psychotherapy, http://pscp/libraries.rutgers.edu

Volume 8, Module 1, Article 1, pp. 1 - 24, 02-18-12 [copyright by author]

“dementia praecox." This new diagnostic term of schizophrenia in one respect was an advance over the older language: it highlighted an experience of the splitting apart of one's sense of personal identity, a subjective catastrophe one sees often enough in those patients to whom this diagnosis becomes applied. One of my patients offered the original translation "torn soul," reflecting her own feeling of inner fragmentation. So, with the term "schizophrenia," the diagnostic system moved in the direction of the patients' phenomenology, which has to be counted as progress. But the word "schizophrenia" is a weird sounding term, and unless one knows Greek, it's roots are obscure. What happened is that it became reified, imagined as the name of an internal illness in mental patients, and then psychiatrists' thinking became captive to their newest brainchild. Today, when we pronounce someone "schizophrenic," that unfortunate soul is regarded as a defective, deficient, and disordered being, suffering from a dreadful illness arising from within. I resist such attributions, and so I speak of “so-called” schizophrenia. In my own clinical practice, I never use the term.

I had an experience with a very disturbed young woman, Anna, which contributed to my thoughts on this matter. She was a 19 year-old who had already been hospitalized for a number of years, and my work with her eventually spanned several decades. There was a central delusion in this case concerning a vicious persecution to which she had become subject. She believed evil "death rays" were emerging from the eyes of her enemies, and these rays crossed space and impacted against her face. Then they turned into tiny, spinning, drilling machines that bored through her skin and skull, finally reaching the soft neural matter deep within. The persecuting rays/machines produced at her brain's center a hardening, almost like a calcification, and the solidified tissues stopped her from having thoughts or feelings and made her feel she was dying. The deadly action of the rays was countered however by a special program of meditations Anna had instituted, intense mental focusing that "dissolved" the inner solidifications and freed her thinking and supported her feeling of being alive. She further explained that once the last solid particles in her nervous system were dissipated, she would undergo a breathtaking transformation she described as becoming "born." The human world was according to her divided into the born and the unborn, and she intended, with my help, to become one of the "born ones." I was, she declared, certainly one of the born ones myself, and I was the individual selected by destiny to be her greatest "birth guard."

It required a number of weeks to become familiar with the persecutory delusion and its details; Anna was mostly mute during this period of our work, quietly pursuing her meditations and explaining nothing to anyone. Once the awful experience with which she struggled finally emerged, the difficulty continued and grew harder still. I could not understand what she was talking about with all the references to birth, rays, machines, solidifications. Responding to this lack of comprehension, she began to experience the death rays as flowing out of my eyes as well. We had a series of meetings in which she would cry out:

Please, stop them [the rays]! They are killing me! I am dying! Oh God, George, you are killing me! Going, going, going.........Gone!

At such moments all communication ceased, as she turned away and refused to speak to me any further. At the next meeting, however, I would be given another chance. 
Psychotherapy as a Human Science: Clinical Case Studies Exploring the Abyss of Madness

Pragmatic Case Studies in Psychotherapy, http://pscp/libraries.rutgers.edu

Volume 8, Module 1, Article 1, pp. 1 - 24, 02-18-12 [copyright by author]

Since I did not understand the symbolism of her delusion at first, I am sure I showed my lack of comprehension in my eyes as she desperately tried to express the ongoing crisis of her life. This situation began to attack her, and she begged me again and again to make the rays stop. I had been drawn into her delusion as often occurs with such patients; but this does not mean that the possibility of a therapeutic outcome is lost. The therapist who has become the destroyer of souls might also turn out to have the power for their resurrection.

What helped us in getting through the impasse was a dream that Anna reported, one that occurred after a visit in the home of her mother. She dreamt she was standing before a tall mirror, looking down a long, tunnel-like hallway. At the other end of the tunnel, her mother appeared, with a loaded revolver. The two of them stood there, facing each other, and slowly the mother raised the pistol and aimed it. A gunshot rang out, the mirror behind Anna shattered into a cloud of tiny, swirling fragments, and she vanished. A disembodied voice then intoned the words: but a shadow on the wall, but a shadow on the wall, as a faint silhouette of something indistinct fleetingly appeared.

The dream and the delusion resemble each other if you look at them closely. In both there is a penetrating action from without, and its result is the killing off of my patient, the murder of her soul. The specific context was a short visit she made to her home on a pass from the hospital, to spend time with her mother. Much of this day had been filled with tension as the mother followed her daughter around the house, saying such things as:

Have you taken your medications yet today? The doctors have given you the medicine to help you! You know you are a sick girl, so don't forget your pills!

This mode of response, replicating the medically oriented treatment Anna also had been receiving in the hospital setting, she experienced as invalidating and discrediting. She did not believe she was mentally ill, and when told so felt attacked. She was someone of enormous vulnerability and sensitivity, who needed a very concrete validation in order to feel that she was even present and in existence. Being viewed and responded to on the basis of a psychiatric diagnosis — schizophrenia, in this case — made her feel shattered and erased. The delusion symbolized this killing effect in a vision of penetrating rays from others' eyes that caused the petrification of her brain and the annihilation of her subjectivity. The dream expressed the killing off of the patient's soul in the image of a gunshot and in the vanishing of her body as she underwent a transforming reduction into nothing more than a fleeting shadow.

I responded to Anna's dream by telling her what I thought it meant, in simple, concrete terms:

What an awful dream, and what an awful visit it was for you. All the commotion with your mother made you totally blown away.

She was happy with these words, and dropped the subject of the dream. Whenever I was able to speak to her in a way that connected to what she felt, she would give a little smile, and then move on to the next thing. 
Psychotherapy as a Human Science: Clinical Case Studies Exploring the Abyss of Madness

Pragmatic Case Studies in Psychotherapy, http://pscp/libraries.rutgers.edu

Volume 8, Module 1, Article 1, pp. 1 - 24, 02-18-12 [copyright by author]

When Anna told me the dream of the gunshot, and I saw the context of its symbolic violence in her experience of her mother's verbal assaults and invalidations, it helped me to understand the delusion as well. I had the thought then that she had presented the dream as a gift to help me understand her. I realized that when she looked into my eyes and encountered my confusion, she felt invaded and undermined. Seeing my uncomprehending looks, she became an incomprehensible psychiatric object and lost all sense of her own personhood. I understood now as well that she was symbolizing this felt violence in the imagery of the rays and the deadly solidifications. She needed me to acknowledge the violence she was experiencing in a direct way; otherwise it could only continue. Here is what I said:

My dear, I have something important to say to you and I want you to listen to it very closely. I know that I have been hurting you, and it has been very, very bad. I see it clearly, and I did not before. Please know that I never intended to bring you harm; it has just been that I didn't understand. Now I do. I hope and I pray that you and I will find a way to undo the damage that has occurred.

The rays from my eyes then ceased to flow. In fact the whole delusion began to recede at this moment, because now she could look at me and know I had caught on to what had been happening to her. That was all that was needed. It is truly incredible how far a little human understanding can go.

To the extent that Anna's "schizophrenia” can be said to have consisted in her delusional thinking, her so-called mental illness here disappeared as a function of a shift in the intersubjective field constituted by our relationship. As in the case of Grace, a psychosis is seen to be relative to a situational context, in this instance one of intrusive, annihilating invalidation.

Another thought about the crisis of Anna's life then arose, stimulated by my friend Michael Gara's interesting suggestion. He offered the idea that the pattern of Anna's delusion concerning the invasive rays and the neural petrifications replicated the structure of the attribution that is made when one person diagnoses another as exhibiting schizophrenia, especially when this mental illness is assumed to include an underlying neurobiological disorder. In the delusion, rays emerge from the eyes of persecutors and enter into and render the core of Anna's brain inert, lifeless, devoid of subjectivity. In the diagnostic attribution, the expressions of the patient's experiences are ascribed to a physical defect, localized as an internal condition deep within her central nervous system. Could Anna's delusion, I wondered, have originally arisen out of her experience of finding herself relentlessly viewed as a chronic schizophrenic? Was her vision of her persecution a concretizing symbol of her experience of being viewed as crazy? Her astonishingly positive response to my validation of my own destructiveness with her would seem to be consistent with such an interpretation. Was her intersubjective situation prototypical of so-called schizophrenia in our time?

I do not want to give the impression that Anna's struggles were over as a result of this little intervention. Her difficulties and vulnerabilities continued, for a great many years. The delusion of the rays and the solidifications, however, vanished and never returned. She was eventually able to leave the hospital where she had spent so long and live with her mother and father. 
Psychotherapy as a Human Science: Clinical Case Studies Exploring the Abyss of Madness

Pragmatic Case Studies in Psychotherapy, http://pscp/libraries.rutgers.edu

Volume 8, Module 1, Article 1, pp. 1 - 24, 02-18-12 [copyright by author]

\section{PSYCHOTHERAPY AS A HUMAN SCIENCE}

A model of psychotherapy that is popular today is found in the "empirically supported treatments" (ESTs) paradigm in which the best practice is understood to be associated with specific manualized treatments that have been shown to be "effective in randomized clinical trials" compared with "treatment as usual" or other "control" conditions for particular disorders. A list of such treatments can be found on the "Research-Supported Psychological Treatments" web site of Division 12 of the American Psychological Association (http://www.div12.org/PsychologicalTreatments/index.html). Generally, on the Division 12 list, there is a predominance of what are known as cognitive-behavioral treatments, which led the chairperson in my university psychology department a few years ago to conclude: "The whole world of psychoanalysis and its derivatives are being called into question."

On the other hand, there has developed an extensive literature critiquing the EST model on such grounds that it ignores (a) context (Datillio, Edwards, \& Fishman, 2010; Elkins, 2009; Westen, Novotny, \& Thompson-Brenner, 2004), and (b) the major role of such common factors as a healing environment, the therapeutic relationship, and the therapist's and client's personal styles (Wampold, 2001; Schneider \& Krug, 2010), all variables that are emphasized in the type of existentially, humanistically, and broadly psychodynamically informed therapy. I have tried to describe and illustrate above. In addition, ESTs ignore the fact that "the vast majority of clients use psychotherapy for support, guidance, and personal growth instead of treatment for mental illness" (Elkins, 2009), that is, for complex life issues rather than discrete mental disorders, as assumed by the medical-model ideas of the EST model. This raises a major question about the close bond between the EST paradigm and the medical model that pigeonholes clients into discrete mental disorders (Elkins, 2009, p. 66). Moreover, a recent article by Shedler (2010) compiles a great deal of compelling empirical evidence documenting the effectiveness of psychodynamic therapy, concluding that "The perception that psychodynamic approaches lack empirical support does not accord with available scientific evidence and may reflect selective dissemination of research findings" (p. 98).

Within the context of this intense discussion going on in the field about the future of psychotherapy, I would like to explore, in light of the above discussion of the cases of Grace and Anna, what I see as the great issues that are challenging the field of psychotherapy today. Perhaps one can imagine a future in which scholars and clinicians will look back on our current situation. What will they say were the most significant questions and problems of our present age?

I picture future scholars looking back upon us as having created the foundation for a new golden age of psychotherapy practice, one that fulfills the latent potential of our field. I am aware that this idea is based on what many would say is blind hope. There are different aspects to it. One emerging theme in our field has to do with a growing attention to phenomenology, and a receding of extrinsic standards against which human lives are measured. A second aspect pertains to an extension of clinical practice to the most severe ranges of psychological disturbances. And a third is about what philosophically inclined analysts sometimes refer to as the "subjectivity" and "intersubjectivity" of our understanding and practice (Atwood \& Stolorow, 1993; Stolorow, Atwood, \& Orange, 2002). 
Psychotherapy as a Human Science: Clinical Case Studies Exploring the Abyss of Madness

Pragmatic Case Studies in Psychotherapy, http://pscp/libraries.rutgers.edu

Volume 8, Module 1, Article 1, pp. 1 - 24, 02-18-12 [copyright by author]

First, let's take phenomenology. Imagine a world of psychiatry and psychology that has escaped the hegemony of the medical model, one that grounds itself in the study of human lives as they are lived and experienced. The diagnostic systems we know today are based on an assessment of so-called "symptoms," which are defined by their status as departures from a preestablished standard of normality or mental health. Imagine a diagnostic framework that instead groups individual worlds of experience, according to the content and themes which they show.

The word "diagnosis," etymologically understood, means a separating and a knowing. I am speaking of worlds of individual experience that can be known and studied. One sees certain resemblances, and certain differences. Placing a descriptive word to indicate the similarities does nothing more than point out their presence. So one can note, for example, that some worlds are marked by a theme of personal annihilation, manifest in repeating experiences of being erased, rendered into nonbeing. Other worlds show a background of stability and substantiality, but within them there is an objectless foreboding, a feeling of being menaced but without any clear focus as to what the threat might be. A third group of worlds, differing from the first two, might be ones in which the personal sense of authenticity has been surrendered in an enslaving pattern of compliance in order to secure otherwise threatened ties to emotionally important others. Noting the presence of these various distinguishing themes and developing a descriptive vocabulary for them places no one in a box and does not get lost in a system of reified mental illnesses. Imagine a future in which we will have a richly developed phenomenological vocabulary, and a wide and deep base of clinical knowledge about the life-contexts in which the various kinds of experiences encountered come into being and are magnified. Imagine as well the accompanying field of psychotherapy practice, in which our ways of approaching people would be uniquely tailored to the content of the individual world of the person turning to us for help.

In years and decades to come, I see our descendants, looking back, focusing on the best that exists already. This leads to the second of the aspects of my hopeful vision: the extension of psychotherapy practice into the most extreme range of psychological disturbances, those human situations currently grouped together as the so-called psychoses.

Our future counterparts fifty and a hundred years hence, as I foresee them, herald the efforts that are being made to devise psychotherapeutic strategies for patients currently labeled 'psychotic.' There have always been people working in our field who have undertaken the most difficult clinical cases—one thinks of Jung (1907), Federn (1953), Sechehaye (1951), Sullivan (1953), Fromm-Reichmann (1954), Winnicott (1958), Laing (1959), Des Lauriers (1962), Binswanger (1963), Searles (1965), Semrad (1980), Karon (1994; 2008), among others. But in our current world such efforts are still the exception, and the consensus is that psychotherapeutic intervention in the psychoses - in particular in what is called schizophrenia and bipolar disorder is an enterprise destined for failure. In the more enlightened age that is to come, if my hope turns out to be fulfilled, such views will be widely regarded as without foundation.

We will be seen as mostly having lived in a dark age, but one sprinkled with points of light. The whole way of conceptualizing psychological disturbances will shift away from the ideas of illness and disorder, and toward the specific human experiences that are involved. We will speak of crises, catastrophes, and chronic dilemmas, and not of dysfunction and disease. 
Psychotherapy as a Human Science: Clinical Case Studies Exploring the Abyss of Madness

Pragmatic Case Studies in Psychotherapy, http://pscp/libraries.rutgers.edu

Volume 8, Module 1, Article 1, pp. 1 - 24, 02-18-12 [copyright by author]

Those things understood as symptoms of pathology will become reinterpreted as symbols of emotional disaster and as attempted restorative reactions in the face of extreme trauma. The emphasis, in other words, will become transposed from what is lacking in relation to an imagined ideal of normality, to an immersion in what is present as a lived experience.

Recall the story of the young woman with whom this essay began, Grace. Her admission to the hospital where I met her was occasioned by a set of visions: golden light had flooded into her bedroom and penetrated into her body. She interpreted this infusion as an experience of sexual union with Jesus Christ. Within the older thinking, the reported flashes of light would be regarded as visual hallucinations, symptoms of a psychosis. Our successors, by contrast, will see such experiences as restorative efforts, albeit dysfunctional from an external vantage point, connected to the tragic circumstances of this young woman's life.

The sexuality was itself a symbol of a coming together, a fusion in which the patient became one with her heart's desire. She was looking toward Heaven in a search for the strength underlying all of creation, and as the golden light flowed into her body and soul, she began to radiate its limitless power herself. It is a commonplace in the phenomenology of grief that one identifies with the person one longs for but has lost. An illusion of that person's presence is thereby generated, in his or her features becoming incorporated into oneself. I see the moment in which the divine energy of God became infused into my patient as symbolic of such an identification. It was a process in which she became the God for whom she longed, undoing her tragic losses and repairing her shattered world. Looking at it in this way, our focus is not on the departure of her experiences from our consensual definitions of what is real; instead we orient ourselves to the inner patterns of Grace's life as she was trying to reconstruct it.

To illustrate further this changing focus, let me tell about some persistent auditory hallucinations of one of my other patients, and I will also recount a dream she reported that helped me to understand the meaning of her voices. This was a young woman in the throes of a bitter divorce from an emotionally abusive husband. There were child custody issues, bitter disputes about a financial settlement, and relentless mutual hatred and accusation. As the divorce process moved along and the cycles of attack and counterattack intensified, my patient began to hear voices calling her various insulting names:

\section{She's a bitch from hell! She's a scumbag whore! She's a liar cunt!}

A paranoid fantasy began to emerge in which conspirators were working against her and trying to destroy her sanity by broadcasting these awful messages on the radio.

Then she had a dream, which was important in understanding what the critical voices actually represented. In the dream, she stood alone in her home, and there were dozens of birds that had somehow gotten beneath the shingles on the roof, penetrating into the walls and the space above her ceiling. They were flying about and making a tremendous racket. It was immediately apparent to me what these terrifying birds symbolized: the hostility and ugly accusations in her divorce battle were finally getting to her, attacking her self-esteem and usurping the integrity of her sense of who she was. Each bird was one of her husband's disparaging attributions, and the felt pressure of his intensifying hatred was finally throwing my patient into an annihilation state. The attack, symbolized by the incursion of the birds into the 
Psychotherapy as a Human Science: Clinical Case Studies Exploring the Abyss of Madness

Pragmatic Case Studies in Psychotherapy, http://pscp/libraries.rutgers.edu

Volume 8, Module 1, Article 1, pp. 1 - 24, 02-18-12 [copyright by author]

very structure of her home, is dealt with in the auditory hallucinations by a kind of reexternalization of the usurping, invalidating opinions. Casting the invaders back into the outside world expresses a need to recover her own boundaries and re-establish the integrity of her own self-experience. The auditory hallucinations and the associated paranoia were thus not "symptoms of an illness"; they were expressions of my patient's efforts to psychologically survive. This is the kind of thinking I envision as an accepted part of our field in its future development. People working with such ideas now are the points of light our counterparts to come will perceive in the vast darkness of our time.

What was my response to learning of my patient's voices? I told her what I thought they signified, that the divorce battle was getting under her skin. I also told her that there was only one voice she should really be listening to, and this all-important voice was none other than her own. I found that this helped with the hallucinations and the paranoia, which began now to recede. The power of my words was of course based on the emotional depth of my connection to the patient, whom I had worked closely with already for a number of years.

Why did the pressure of this woman's husband's hatred begin to usurp and annihilate her? The vicious attacks by the husband replicated equally vicious emotional assaults the patient experienced as a young child by her mother. She was a survivor of extreme child abuse, and the emotional violence and the invalidations of her early years were reawakened in her disintegrating marriage. When one sees such reactions there is almost always a current situation having effects that repeat and resurrect an earlier one.

In sum, in my view psychotherapy is a human science, and as psychotherapists we learn from the narrative accounts that are given of the journeys we undertake with our patients. Principles of interpretation and intervention inhere in such accounts, and if these principles can be successfully communicated to others working in our field, then knowledge is thereby being disseminated and confirmed. We do our clinical work, and then we tell one another stories about it. An important component of the evidence for there having been something positive that has occurred lies inside the stories that are given. Sometimes the accounts are provided by our patients themselves. Read two magnificent, classic books: I Never Promised You a Rose Garden (Greenberg, 1962) and Autobiography of a Schizophrenic Girl (Sechehaye, 1954). These works describe two journeys in psychotherapy that were incontestably effective in helping the patients find new ways to live in this world.

\section{"SO-CALLED" BIPOLAR DISORDER}

Among the phenomena we conventionally see as "symptoms" in severe psychological disturbances would be shifting, cycling mood states. Do these also become reinterpreted as restorative as in the case of many hallucinations and delusions?

So-called bipolar disorder is of course the crowning instance of such shifts and cycles. This quintessentially psychological phenomenon, as I would understand it, has in our time been wrongly ceded to the biological psychiatrists, the reductionists who are true believers in genetic and biochemical origins. In my view, our friends in the future will shake their heads in dismay at the virtually complete disconnect between the medical certainties that are maintained about this 
Psychotherapy as a Human Science: Clinical Case Studies Exploring the Abyss of Madness

Pragmatic Case Studies in Psychotherapy, http://pscp/libraries.rutgers.edu

Volume 8, Module 1, Article 1, pp. 1 - 24, 02-18-12 [copyright by author]

matter and the poverty of supporting scientific evidence. There have been, however, points of light in the history of our field that concern the phenomenological basis of this condition.

There was a faint glow in the early observations and interpretations of Melanie Klein, who wrote about this topic (1934). The conflicts belonging to what she called the depressive position were central in her conceptualization, wherein the child suffers in an experience of his or her aggression being dangerous to the survival of the parenting figure. Unfortunately, she was limited by an imprisoning theory of innate drives that obscured her phenomenological insight into what children in the midst of profound enmeshment feel about their own aggressive, selfassertive impulses.

I think also of Frieda Fromm-Reichmann, who studied bipolar patients intensively (1954). She concluded that as children they were never treated as distinct persons, but instead were viewed as extensions of their caregivers. Then we have Donald Winnicott, who elaborated the idea of the manic defense (1962) — in particular he made the interesting suggestion that mania is a protection against not just depression, but against an underlying state of psychic death.

Finally we come to my dear friend Bernard Brandchaft (1993), who had the luminous idea that manic-depressive patterns are concerned with a struggle against the experience of personal annihilation. Put most simply, the meaning of mania, according to him, is that it embodies a transitory liberation from an enslaving, annihilating tie to emotionally important others, whereas the depression into which a manic patient collapses represents the reinstatement of that tie. There may be other pathways to bipolarity, but I have found Brandchaft's ideas abundantly illustrated among the many such patients I have observed.

I consider the psychotherapy of the so-called bipolar patient to be possibly the single most important contemporary frontier of clinical psychoanalytic research, but I cannot say that our knowledge in this area has advanced very far. I will offer a few thoughts that have come to me over the years in which I have given this problem consideration.

\section{The Case of "Thomas"}

A first idea appeared in a consultation with a colleague some years ago. My associate, a psychiatrist, sought my advice regarding what he thought was a sudden turn for the worse in a bipolar patient he had been treating for a very long time. This patient, a 45 year-old man whom I will call "Thomas," had shown a classic manic-depressive pattern, oscillating violently between the extremes of uncontrolled euphoria and suicidal depression. He had been hospitalized a number of times, there had been serious attempts to kill himself, and he had squandered all his family's money in spending sprees and hair-brained investments. My colleague had persisted with this man through a number of these crises, trying to help him basically by just being emotionally available and always maintaining their schedule of psychoanalytic sessions three times each week.

Now, however, in the aftermath of Thomas' latest bout of disruptive mood swings, something else had appeared. The man informed his analyst that he, the patient, had suddenly recognized that he was in absolute control of all his analyst's thoughts. Hearing of this reported mental omnipotence, my colleague concluded his patient was sinking into a delusional state. 
Psychotherapy as a Human Science: Clinical Case Studies Exploring the Abyss of Madness

Pragmatic Case Studies in Psychotherapy, http://pscp/libraries.rutgers.edu

Volume 8, Module 1, Article 1, pp. 1 - 24, 02-18-12 [copyright by author]

This was very depressing for him, because he had given of his time and energy to this man for a number of years. I asked him to say more about his patient, about what it had been like to work with him for this long period. Something interesting then appeared.

He told me that his patient's emotional life had always been strangely opaque, almost as if it did not exist. On the first occasion, near the beginning of their meetings, when asked how he was feeling, the patient had been nonplussed. He said no one had ever asked him such a question, and he did not have any idea about what his "feelings" were. He said he did not know what the word "feelings" even meant. He was familiar with the overwhelming rush of his manic states, and he knew about wanting to die. But he was a man who reported that there was no emotional life otherwise that could be described. He could not introspect or reflect, had no vocabulary for expressing what he experienced, and if pressed on the matter became very upset.

I wondered aloud about whether this absent inner life pertained to a developmental background that was an empathic vacuum, devoid of human understanding and offering nothing to help him develop a language articulating his emotions. This had not occurred to my colleague, who had seen his patient's opaqueness - his alexithymia-as some kind of congenital peculiarity that needed no further explanation. He confirmed, however, the idea that there had never been any talk about emotions in the patient's family, because the parents had related to their son as a purely exterior being, almost as if they were some sort of strange behaviorists. They focused on his actions, and their approval of him was strictly conditional on whether or not he met their very high standards of conduct. There were indications, according to the psychiatrist, that the parents' avoidance of their child's inner life pertained to a terror of psychosis on their parts.

Then further questions arose in my mind, especially about Thomas' so-called delusion concerning having absolute control over all his analyst's thoughts. What if, I wondered, this seeming delusion expressed the arrival of a miracle in the patient's world: an experience of actually commanding the attention of another human being? What if the absence of an emotional life was the secondary effect of missing empathy, of profoundly absent emotional attunement in his family of origin? Maybe no one ever took the time to sit down and listen to him. A child who is never listened to is subject to annihilation.

What if, I continued to ask, this man grew up among people who saw him as the normal, conventional child they needed him to be instead of the one he actually was? What happened then to the person he might otherwise have become? My answer is: that person may have vanished, almost without a trace, as a life unfolded in a structure of compliance that embodied an identity borrowed from his caregivers' expectations.

Sometimes such a situation eventuates in an anorexic pattern, wherein the experience of the deprivation of emotional attention is symbolized in the repeating acts of self-starvation. The sense of agency that is given up in conforming to parental pressures and becoming the child that is wanted and approved of, in anorexia, reappears in an active refusal of the intake of nourishment. There the exercise of absolute control over what physical substances pass into the body stands in contrast to the passive compliance in which the child surrenders to being authored by the external human surround. Here again we see something conventionally regarded as a 
Psychotherapy as a Human Science: Clinical Case Studies Exploring the Abyss of Madness

Pragmatic Case Studies in Psychotherapy, http://pscp/libraries.rutgers.edu

Volume 8, Module 1, Article 1, pp. 1 - 24, 02-18-12 [copyright by author]

symptom of an illness that is better understood as an expression of a will to exist and survive. Obviously there is also a paradox, in that the agentic self-assertion implicit in the anorexic starvation project also often brings about biological death.

In other instances, as in the case of Thomas, the patient about whom I was being consulted, a manic-depressive cycle springs into being, one in which the positions of surrender through compliance and of rebellion and protest alternate with each other. Keeping all of this in mind, the idea the patient evinced that he had absolute control over his analysts thoughts could be considered an amazing breakthrough, a first form of an experience of attunement heralding the possibility of an emotional life arising that belongs to the patient and that could result in a freedom from the deadly cycles of bipolarity.

I suggested to my colleague that he seek ways of validating, mirroring, and really celebrating the experience Thomas was now having of being in command of his thoughts and feelings. I told him that this feeling, being so utterly new, must also be a tenuous and unstable sort of thing, and that perhaps the need to hold on to this emergent sense was causing him to concretize and elaborate it in a seeming delusion.

Unfortunately, my colleague was unable to follow my advice, focusing instead on the disparity between his patient's new claims of omnipotence and the content, as he saw and defined it, of objective reality. A battle ensued between the two of them, and the opportunity to support the patient's apparent development was lost. I was told my advice made no sense, because it is not good clinical practice to encourage delusional thinking. My colleague chose instead to interpret his patient's imagined control as a wish fulfillment, counteracting the effects of their separations between sessions of the psychotherapy. Thomas rejected this idea, and then ceased to speak of controlling his therapist's mind.

I was able to follow up on this case a few years later when I had an opportunity to contact my colleague again. I asked him what had occurred in the period subsequent to the episode regarding which I had provided a consultation. He said that in the months following the remarkable claim of mental control, his patient had repeatedly accused him of trying to make him conform to some standard model of mental health, much as his parents had tried to mold him into an ideal child. A dream the patient presented at the time seemed to symbolize his struggle. In that dream he was being pursued by a gang of terrifying zombies, who chased him up the stairs to his psychiatrist's office in an effort to kidnap him. After a period of a year, Thomas abruptly terminated his sessions with his therapist.

My colleague, in interpreting the patient's seeming delusion, followed in the spirit of Freud's (1924) understanding of psychotic states as involving a turning away from a frustrating external reality in favor of a substitute imaginary world in which irresistible desires are fulfilled. Offering such an idea invalidates emergent modes of experience that, on account of being new and unstable, become cast into a language of concretizing symbols. So often the potential to move beyond the place of one's injury and imprisonment is subverted by the blinding certainties of those to whom one turns for help.

Nevertheless, I think it would be worthwhile to pursue the sort of thing this case presented. Perhaps other patients, followed intensively for long enough, could develop in a 
Psychotherapy as a Human Science: Clinical Case Studies Exploring the Abyss of Madness

Pragmatic Case Studies in Psychotherapy, http://pscp/libraries.rutgers.edu

Volume 8, Module 1, Article 1, pp. 1 - 24, 02-18-12 [copyright by author]

similar way, and one could discover whether an aborted developmental process could then be reinstated within the medium of the patient's experience of his therapist's empathy. This would require great dedication and long periods of time. One would have to be prepared to live through the crises, do what one could to avert the patient's complete self-destruction, and then hope that the needed underlying connection of empathy and validation could crystallize. People in our field today want quick results, so they turn to electroconvulsive therapy, lithium carbonate, and the like to address manic-depressive experiences. In the golden age of psychotherapy that I predict is to come, it will be understood that genuine healing is not likely to come quickly.

\section{The Case of "Mary"}

Some related thoughts arise out of more recent efforts I have made to help a young woman, whom I will call "Mary," who carried this diagnosis. She had experienced, in her late teens and early twenties, a number of manic episodes, requiring hospitalizations and eventuating in a high number of electroconvulsive treatments. She came to me when she and her family began to see that the ECT was having a devastating impact on her memory and cognitive functioning.

I was interested in her description of the experience of Mary's most recent mania. She explained that the chaos of her adult life had never bothered her much, because she had relied instead on the treasures of her own mind, on the fascinating intricacies of her rich imagination. She had been able always to escape her oppressive life situations--for example, of being a college student unable to complete her studies, or of being a young woman who was fast becoming a terrible disappointment to her parents_-by turning to fantasy, to thrilling, exhilarating images of herself and her life in a world apart from this one. The problem was that when she gave herself over to this alternative reality, she also lost all control of her own thoughts and feelings. Glorious plans and dreams of unparalleled grandeur would materialize, and when she then was driven to enact these, disaster would occur, with hospitalization following along soon thereafter. As we spoke, I learned that she had, in her younger years, tried mightily to please her parents and other authorities, striving always for perfection and success. She had in fact become a slave to the goal of being a perfect golden child.

As she suffered under this imprisonment in her late teens, however, in the context of a series of disorienting changes and losses in her personal situation, a wonderful universe of freedom suddenly opened up before her mind, one she plunged into with joyful enthusiasm. This was a realm of liberation she had never known, and its intoxicating power became irresistible.

But then her newly crystallized plans and dreams led to catastrophe, and she was subjected to hospitalization, antipsychotic medications, and electroshock therapy. The child who had existed earlier and who had sought to please her family reappeared. Back and forth she went over the next several years, between uncontrolled manic highs and conformist depressive lows, and her electroconvulsive treatments and her lithium ultimately could not stop these oscillations, or they did so only at the expense of the functioning of her own mind. Then she and her family found their way to me.

I asked Mary what she wanted. She answered that she wanted to live for herself. That became the theme of our connection. She complained of there being “voices,” haunting, 
Psychotherapy as a Human Science: Clinical Case Studies Exploring the Abyss of Madness

Pragmatic Case Studies in Psychotherapy, http://pscp/libraries.rutgers.edu

Volume 8, Module 1, Article 1, pp. 1 - 24, 02-18-12 [copyright by author]

whispering presences that criticized and devalued her in every situation she encountered. I told her, as is my habit in such cases, that there was only one voice she should pay attention to: that would of course be just her own. She sat with that declaration for a moment or two, and then said to me:

\section{You are a practitioner of "I-therapy," aren’t you? You seem like you are all for "I."}

I answered that indeed I was one who believed in "I," and regarded "I" as sacred and therefore to be protected and honored in every way possible. The young woman seemed at this point to relax in my presence, and told me much more about the voices she heard and the siren-call of the images that embodied freedom and glory.

A shared understanding seemed to appear in our long discussions of her adventures over the previous years of her life, one in which her extreme mood swings were viewed as alternations between trying to be perfect and pleasing to others on the one hand, and seeking profound emancipation from such efforts on the other. The lure of the manic states was very strong, always promising to deliver wonderful gifts, but leading in every instance to disaster. The depressions following her highs were very severe, filled with the critical voices, and often provoking a suicidal despair. She and I said to each other that the key to her recovery would be found in the achievement of a new balance between these polarized alternatives, an equilibrium which would not be one of perfection and which would also not require or involve infinite freedom. She said, and I agreed, that only she could establish and maintain this balance. She also suggested a metaphorical image for my role as her psychotherapist in this endeavor in search of a new personal center: I was to be her lighthouse, a point of reference in the night and in whatever storms might arise, one to which she could look in advancing her journey toward stability.

I have only known Mary for a few years. She has had her ups and downs in this period but we have succeeded in avoiding any further ECT. In the meantime she continues to experience her therapy as a lighthouse, one that helps keep her "I" on its pathway, and we are hopeful that over time the stable life she seeks will become hers. I am thinking we will need at least a decade in this process, so we shall see.

Mary has increasingly assimilated my presence in her life as an ally and resource for the support of her sense of "I-ness," and I think this would be an indispensable precondition for the successful treatment of the so-called bipolar patient. Without a connection that is felt to be sustaining and supporting in this way, the psychotherapist can only be seen as an agent of society, one of the forces pushing the patient in the direction of normality and compliance. That is a recipe for psychological death in the lives of such people, who will then be condemned to the manic-depressive cycles without end.

Something has happened in the lives of bipolar patients to sever the connection between accommodative and individualizing trends in their personalities. In mania we see a roman candle shooting out the fires of pure freedom and uniqueness. In the depressions which later ensue, one witnesses the extinction of the flames of liberty, as the darkness and despair of surrender to the agendas of family and society rush in. Something needs to occur to mend the rift that has opened up in the core selfhood of the patient, something that will bridge the two 
Psychotherapy as a Human Science: Clinical Case Studies Exploring the Abyss of Madness

Pragmatic Case Studies in Psychotherapy, http://pscp/libraries.rutgers.edu

Volume 8, Module 1, Article 1, pp. 1 - 24, 02-18-12 [copyright by author]

stark alternatives and establish a stability free of the bipolar swings. This something is the work of the therapy, and it can only occur as a result of the patients' own volitions. The effort of this work, in turn, can only be sustained in the facilitating presence of an other who can be a lighthouse for the journey. This would be an example of the principle that the 'I' can only come into being in relation to an answering and orienting 'Thou' (Buber, 1923).

The pathway of the journey will often involve creative works in some way. The act of creation, in all areas of art and literature and philosophy, offers abundant opportunities for integrating conflicting currents in our natures, for bridging rifts that have opened up in the warfares of bipolarity. My patient Mary, for example, made great strides in pulling herself together in a developing career in modern dance. Others I have known or studied found in poetry their pathways toward unification, or in musical composition, or in the elaboration of interesting, integrative philosophical doctrines. This is an area in which there need to be continuing studies of all the ways people find to heal their fractured souls (Atwood, 2011, Chapter 9). Extensive knowledge of such matters, in turn, will prepare clinicians for their sacred roles as lighthouses in the stormy travels of the patients who turn to them for help. We are still at the beginning of the long process of developing this knowledge.

\section{THE PLACE OF THE THERAPIST}

This third aspect of what I hope I am seeing in the contemporary development of our field has to do with the radical engagement of the person of the therapist in whatever process of psychotherapy occurs. What does the term "radical engagement" mean in this context? It means that the therapist, as an individual, is implicated in everything that takes place within the psychotherapeutic dyad. It means that there is no such thing as detached observation. It means that the transformations that occur, if any do, include both participants.

My use of the term "implicated" might seem to indicate a crime of some sort has occurred. The things that happen in what is called psychotherapy or psychoanalysis often enough are crimes, emotional crimes committed against those we are entrusted to help. But that is not the connotation I want to highlight. It is more the idea that the imprint of the therapist's subjectivity, of his or her personality, is everywhere present in the psychotherapeutic process. Psychotherapy, far from being any sort of procedure that is administered from a place of detachment, is always a dialogue between two personfal universes, one that transforms both.

On more than one occasion at psychoanalytic conferences, I have been asked how it is then that we are to distinguish which of the people involved in an analysis is the patient. I become impatient with such questions, and once suggested that one can see which is which by determining which one is crying. Of course that doesn't work when the patient does something so upsetting that the therapist breaks into tears.

A psychotherapeutic dialogue, if it is in any measure successful, always illuminates and transforms the worlds of both of the people involved, and as far as I am concerned, this is actually self-evident. 
Consider again my early clinical experience with Grace, my religious patient who visualized herself as part of the Holy Trinity. Her journey of healing utterly transformed my understanding of the whole realm of severe psychological disturbances and of the potential of psychotherapy to address them. Recall her promise that she would raise me up from someone small and weak into a position of strength and power. She certainly succeeded in doing that. I could also speak of the effect of witnessing her struggle with her father's suicide as her mourning process unfolded. I could not follow these developments without a corresponding opening up of my own early experiences of trauma and loss. To see someone coming to the truth of his or her life is, inevitably, to be brought closer to the truth of one's own. In the golden age of psychotherapy practice that is to come, this idea will be axiomatic.

All the phenomena of psychotherapy will be understood as taking place within an intersubjective field, one that creates a constitutive context for the experiences and actions of both analyst and patient.

\section{REFERENCES}

Atwood, G.E. (2011). The abyss of madness. New York, N.Y.: Routledge.

Atwood, G.E. \& Stolorow, R.D. (1993). Faces in a cloud: Intersubjectivity in personality theory. Jason Aronson: Northvale, NJ.

Atwood, G.E., Stolorow, R.D., \& Orange, D.M. (2002). Shattered worlds/psychotic states: A post-Cartesian view of the experience of personal annihilation. Psychoanalytic Psychology, 19, 281-306.

Binswanger, L. (1963). Being in the world. New York: Basic Books.

Bleuler, E. (1911). Dementia Praecox or the group of schizophrenias. Madison, Connecticut: International Universities Press, 1950.

Brandchaft, B. (1993). To free the spirit from its cell. In R.D. Stolorow, G.E. Atwood, \& B. Brandchaft (Eds.), The intersubjective perspective, pp. 57-76. Northvale, NJ: Jason Aronson.

Bleuler, E. (1911). Dementia Praecox or the group of schizophrenias. Madison, Connecticut: International Universities Press, 1950.

Buber, M. (1923). I and Thou. (W.A. Kaufmann, Trans.) New York: Scribner, 1970.

Dattillio, F.M., Edwards, D.J.A., \& Fishman, D.B. (2010). Case studies within a mixed method paradigm: toward a resolution of the alienation between researchers and practitioners in psychotherapy research. Psychotherapy: Theory, Research, and Practice, 47, 427-441.

Des Lauriers, A.M. (1962). The experience of reality in childhood schizophrenia. New York: International Universities Press.

Elkins, D.M. (2007). Empirically supported treatment: The deconstruction of a myth. Journal of Humanistic Psychology, 47, 474-500.

Federn, P. (1955). Ego psychology and the psychoses. New York: Basic Books.

Freud, S. (1924). The loss of reality in neurosis and psychosis. In J. Strachey (Ed. \& Trans.), The standard edition of the complete psychological works of Sigmund Freud, vol 19, pp. 183-187. London: Hogarth Press.

Fromm-Reichman, F. (1959). An intensive study of 12 cases of manic-depressive psychosis. In D. Bullard (Ed.), Psychoanalysis and psychotherapy: Selected papers of Frieda FrommReichman, pp. 227-274. Chicago: University of Chicago Press. 
Psychotherapy as a Human Science: Clinical Case Studies Exploring the Abyss of Madness

Pragmatic Case Studies in Psychotherapy, http://pscp/libraries.rutgers.edu

Volume 8, Module 1, Article 1, pp. 1 - 24, 02-18-12 [copyright by author]

Greenberg, J. ( 1964). I never promised you a rose garden. Orlando, Fla.: Holt, Rinehart, \& Winston.

Jung C.G. (1907). The psychology of dementia praecox. In G. Adler, H. Read, \& R.F.C. Hull (Eds. and Trans.), The collected works of C.G. Jung: Vol. 3, The psychogenesis of mental disease, pp. 1-152. New York: Bollingen Foundation.

Karon, B. \& VandenBos, G. (1994). Psychotherapy of schizophrenia: The treatment of choice. Northvale, NJ: Jason Aronson.

Karon, B. (2008). An "incurable" schizophrenic: The case of Mr. X. Pragmatic Case Studies in Psychotherapy [Online], Vol. 4(1), Article 1, 1-24. Available: http://hdl.rutgers.edu/1782.1/pcsp_journal

Klein, M. (1934). A contribution to the psychogenesis of manic depressive states. In Contributions to psychoanalysis, pp. 282-310. London: Hogarth Press.

Laing, R.D. (1959). The Divided Self. London: Tavistock.

Schneider, K.J., \& Krug, O.T. (2010). Existential-humanistic therapy. Washington, DC, US: American Psychological Association.

Searles, H. (1965). Collected papers on schizophrenia and related subjects. London: Hogarth Press.

Sechehaye, M. (1951). Autobiography of a schizophrenic girl. New York: Signet.

Rako, S., \& Mazer, H. (1980). Semrad: The heart of a therapist. Northvale, NJ: Jason Aronson.

Shedler, J. (2010). The efficacy of psychodynamic therapy. American Psychologist, 65, 98-109.

Stolorow, R.D., Atwood, G.E., \& Orange, D.M. (2002). Worlds of experience: The interweaving of philosophy and psychoanalysis. New York: Basic Books.

Sullivan, H.S. (1953). The interpersonal theory of psychiatry. New York: W.W. Norton \& Co.

Westen, D., Novotny, C. M., \& Thompson-Brenner, H. (2004). The empirical status of empirically supported psychotherapies: Assumptions, findings, and reporting in controlled clinical trials. Psychological Bulletin,130, 631-663.

Wampold, B.E. (2001). The great psychotherapy debate: Models, methods, and findings. New York: Routledge

Williams, P. (2011). A multiple-case study exploring personal paradigm shifts throughout the psychotic process from onset to full recovery. Unpublished, open access doctoral dissertation, Saybrook Graduate School and Research Center, San Francisco. Available: http://gradworks.umi.com/34/54/3454336.html.

Winnicott, D.W. (1958). The manic defense. In Collected papers: Through paediatrics to psychoanalysis, pp. 129-144. New York: Basic Books. 